\title{
Resistance of Eucalyptus Clones to Ceratocystis fimbriata
}

E. A. V. Zauza and A. C. Alfenas, Department of Plant Pathology, Federal University of Viçosa, Viçosa-MG, 36571 000, Brazil; T. C. Harrington, Department of Plant Pathology, Iowa State University, Ames 50011; E. S. Mizubuti, Federal University of Viçosa; and J. F. Silva, Suzano Bahia Sul Company, Teixeira de Freitas, Bahia 45995-000, Brazil

\begin{abstract}
Zauza, E. A. V., Alfenas, A. C., Harrington, T. C., Mizubuti, E. S., and Silva, J. F. 2004. Resistance of Eucalyptus clones to Ceratocystis fimbriata. Plant Dis. 88:758-760.

Ceratocystis fimbriata, the inciting agent of wilt, canker, and dieback in eucalyptus plantations, was first reported in Brazil in 1998. There is no information regarding the resistance of Eucalyptus spp. to this pathogen. We determined the reaction of 18 Brazilian, commercial clones of the hybrid Eucalyptus grandis $\times$ E. urophylla to inoculation by two isolates of the pathogen in two experiments. Container-grown, 8-month-old rooted cuttings of each clone were woundinoculated with a conidial suspension $\left(2.5 \times 10^{6} / \mathrm{ml}\right)$. Plants similarly injected with sterile distilled water served as controls. The plants were evaluated after 30 days for length of xylem discoloration. There was a significant isolate by clone interaction, but most clones reacted similarly to the two isolates. Six clones, including one observed to be highly susceptible under field conditions, were highly susceptible ( $>20 \mathrm{~cm}$ discoloration) to one or both isolates of the pathogen. Four clones showed no more discoloration with either isolate than with the control inoculations, and the other eight clones were intermediate in susceptibility. Thus, highly resistant clones are available to manage this disease.
\end{abstract}

Additional keywords: clonal propagation

Ceratocystis fimbriata Ellis \& Halst. is widely distributed in the world, especially in the Americas $(3,7)$. The fungus generally infects through wounds and moves through xylem tissues in a wide range of hosts, but considerable host-specialization within $C$. fimbriata has been demonstrated based on xylem discoloration in woundinoculated plants (1). The pathogen causes rots in storage roots of Ipomoea batatas and corms of Colocasia esculenta, wilt of Crotalaria juncea, and wilt, canker, and crown dieback in coffee (Coffea arabica), cacao (Theobroma cacao), mango (Mangifera indica), sycamore (Platanus spp.), Prunus spp., Gmelina arborea, Populus spp., wattle (Acacia spp.), and rubber tree (Hevea brasiliensis) (3). Wilt and canker caused by $C$. fimbriata on eucalyptus was first reported in 1998 in plantations of a Eucalyptus grandis $\times$ E. urophylla hybrid in southern Bahia, Brazil (6). Among Brazilian isolates of $C$. fimbriata, only eucalyptus isolates appeared pathogenic to eucalyptus (1). The disease has recently been reported in E. urophylla $\times E$. pellita and E. tereticor$n i s \times E$. grandis from the Republic of Congo (13) and in E. grandis from Uganda (12) and Uruguay (2). Congolese isolates were pathogenic to an E. grandis $\times E$.

Corresponding author: T. C. Harrington

E-mail: tcharrin@iastate.edu

Accepted for publication 16 March 2004.

Publication no. D-2004-0510-01R

(C) 2004 The American Phytopathological Society camaldulensis clone in an inoculation experiment (13). The strains from Africa and Uruguay have internal transcribed spacer (ITS)-rDNA sequences $(2,12,13)$ very similar to those of Bahian isolates of $C$. fimbriata from E. grandis $\times$ E. urophylla (1), and the pathogen may be spreading from Bahia via infected cuttings. In both Africa and South America, substantial mortality can result in some plantations, and this emerging disease is of great concern.

Eucalyptus species are the most economically important forest plantation species in Brazil, where they are cultivated on 3 million hectares, representing about $22 \%$ of the world's afforested areas under eucalyptus (11). Eucalyptus is a major source of raw material for cellulose, paper, coke for the steel industry, furniture, railway sleepers, fence stakes, and posts. Clonal propagation permits the annual production of millions of uniformly fast-growing genotypes with homogeneous fiber characteristics and also facilitates development and deployment of disease resistance, if resistant clones can be identified. Because Eucalyptus spp. are native to Australia and the eucalyptus form of $C$. fimbriata likely is not $(1,7)$, there was some doubt if suitable resistance could be found. This study was done to evaluate resistance to $C$. fimbriata in currently available eucalyptus clones used for planting and in breeding programs in Brazil.

\section{MATERIALS AND METHODS}

Two eucalyptus isolates (UFV $182=$ C1345 and UFV $247=\mathrm{C} 1442$ ) of $C$. fim- briata were used. Both isolates were from diseased eucalyptus near Teixeira de Freitas, Bahia, Brazil, and were shown to be pathogenic to eucalyptus in a separate study (1). The isolates were used in two inoculation trials (experiments) in December 2000 and March 2001 in a nursery at the Federal University of Viçosa, Minas Gerais, Brazil. Daily high temperatures during these periods were $25 \pm 3^{\circ} \mathrm{C}$. In each trial, three rooted cuttings of each clone were inoculated with each isolate, and three rooted cuttings served as controls. For preparation of the conidial suspension, the fungus was grown in petri dishes $(9 \mathrm{~cm}$ diameter) containing malt yeast extract agar (MYEA; 2\% malt extract, $0.2 \%$ yeast extract, and $2 \%$ agar) for 8 days at $28^{\circ} \mathrm{C}$ with a photoperiod of $12 \mathrm{~h}$. Ten milliliters of sterile deionized water was added to the surface of the plates, and the mycelium was scraped with a sterile spatula. The conidial suspension was filtered through sterile cheesecloth and the concentration adjusted after counting with a hemacytometer.

The eucalyptus clones were selected from commercially available hybrids of $E$. grandis $\times E$. urophylla. The hybrids were collected from an orchard in which $E$. grandis females were open pollinated by E. urophylla males. Many progeny were cloned and proven to be superior for form and fast growth at a number of sites in Brazil. Cuttings from 18 of these elite clones were grown in a soil/manure mixture $(3: 1 \mathrm{vol} / \mathrm{vol})$ in 2-liter containers under nursery conditions. The 8-month-old plants of 1.5 to $2.0 \mathrm{~cm}$ diameter were inoculated as described by Laia et al. (9) by injecting a small, vertical slit in the bark of the lower stem (about $3 \mathrm{~cm}$ above soil surface) with $1 \mathrm{ml}$ of a conidial suspension $\left(2.5 \times 10^{6} / \mathrm{ml}\right)$ using a sterile syringe (needle gauge 21). The control plants were similarly injected with sterile distilled water. The injection site was wrapped with Parafilm.

The plants were distributed randomly on nursery benches and watered by sprinkler irrigation three times a day or as needed. The plants were evaluated at 30 days for the length of xylem discoloration by cutting lengthwise into the stems as described previously (1). A multi-factorial analysis of variance (ANOVA) and Fisher's protected LSD test (data from the two experiments combined) were conducted using SAS statistical software (SAS Institute, Cary, NC). 
Table 1. Analysis of variance of the length of xylem discoloration in clones of Eucalyptus grandis $\times$ E. urophylla in response to inoculation with two isolates of Ceratocystis fimbriata

\begin{tabular}{lrrrl}
\hline Source & df & \multicolumn{1}{c}{ MS } & $\boldsymbol{F}$ value & $\boldsymbol{P}>\boldsymbol{F}$ \\
\hline Clone & 17 & $1,148.00$ & 95.08 & 0.0001 \\
Isolate & 1 & 884.12 & 73.22 & 0.0001 \\
Experiment & 1 & 17.34 & 1.44 & 0.2327 \\
Clone $\times$ isolate & 17 & 136.56 & 11.31 & 0.0001 \\
Clone $\times$ experiment & 17 & 5.20 & 0.43 & 0.9760 \\
Isolate $\times$ experiment & 1 & 4.39 & 0.36 & 0.5474 \\
Clone $\times$ isolate $\times$ experiment & 17 & 3.98 & 0.33 & 0.9945 \\
\hline
\end{tabular}

\section{RESULTS}

There were no wilt symptoms or mortality within the 30-day period. However, there was substantial variation in the length of xylem discoloration among the clones and between the two isolates, and there was significant clone by isolate interaction (Table 1). There was no significant difference between the two experiments (Table 1 ), however, and the results of the two experiments were combined (Table 2).

The clones varied from highly resistant (almost immune) to highly susceptible based on the length of xylem discoloration. The length of discoloration in clones $\mathrm{C} 15$, C16, C17, and C18 inoculated with either isolate was no greater than that found in the noninoculated controls. Clones C13 and $\mathrm{C} 14$ were moderately resistant to both isolates. Generally, more discoloration was found with isolate C1442 than with C1345, and six clones inoculated with isolate C1442 had greater than $20 \mathrm{~cm}$ discoloration. Clone $\mathrm{C} 1$ was highly susceptible to both isolates. The remaining six clones had between 4 and $20 \mathrm{~cm}$ discoloration with both isolates and could be considered intermediate in susceptibility (Table 2).

\section{DISCUSSION}

This is the first study reporting the resistance in eucalyptus to $C$. fimbriata, a new and potentially important pathogen of this highly valuable crop. Resistance to $C$. fimbriata has also been found in Theobroma cacao and Coffea arabica, and this resistance has proven valuable in disease management $(4,5,8,10,14)$. Thus far, the pathogen has caused substantial mortality in only a few clones of $E$. grandis $\times E$. urophylla in Brazil. Among the clones we inoculated, only the susceptible clone C4 has been widely planted in Bahia, and the disease has been especially severe in this clone. However, other clones proved to be highly resistant or nearly immune, and these clones are currently being evaluated in the field.

The differences in aggressiveness of the two isolates to eucalyptus can be attributed to the genetic variability in $C$. fimbriata $(1,7)$. However, the two isolates we used caused similar amounts of discoloration in the various clones and did not appear to differ greatly in aggressiveness. Baker et al. (1) inoculated rooted cuttings of clone $\mathrm{C} 4$ with the same eucalyptus isolates (C1345 and C1442) that we used and found substantial discoloration, but a third eucalyptus isolate apparently lost pathogenicity and caused no more discoloration than the controls or the isolates from other hosts (cacao, mango, and Gmelina arborea). Isolates $\mathrm{C} 1345$ and $\mathrm{C} 1442$ were not pathogenic to cacao or Gmelina arborea but were pathogenic to mango (1). More work is needed on the host range and variation in aggressiveness among Brazilian isolates of $C$. fimbriata.

Work is also needed to determine the ideal age to evaluate resistance in the $C$. fimbriata/Eucalyptus pathosystem, but xylem discoloration, rather than mortality, appears to be a more replicable parameter for evaluating susceptibility and resistance (1). Lack of wilt or mortality in our trials may be related to plant age, and young plants under optimum growth conditions may die more quickly than older plants. In another test (unpublished data), 4-monthold plants of clone $\mathrm{C} 4$ wilted and died within 12 days of inoculation with an isolate of $C$. fimbriata from eucalyptus.

Clones with known susceptibility, such as $\mathrm{C} 1$ and $\mathrm{C} 4$, should not be planted in areas where the pathogen is known to be present. However, clone C4 has many superior characteristics, such as high cellulose yield, low levels of extractives, fast growth, precocious shedding of branches, and resistance to canker caused by Cryphonectria cubensis. Progeny from controlled crosses between elite E. grandis $\times$ E. urophylla genotypes, including clone C4, were planted in November 2002 to January 2003 in an area of South Bahia with a history of mortality caused by $C$. fimbriata. The results are preliminary, but segregation for susceptibility/resistance has been observed in the progeny from all the crossings involving clone $\mathrm{C} 4$ and in progeny from the $\mathrm{C} 4$ selfings (unpublished data). Artificial inoculations will be made to confirm the inheritance of susceptibility, and further efforts will be made to breed for resistance.

Besides avoidance of susceptible clones and use of resistant clones, management of the disease might include removal and destruction of infected plants, minimization of wounding (infection courts), and rotation with nonhost plants (3). The pathogen also appears to be spreading to new areas in infected cuttings $(1,7)$, and care should be taken not to vegetatively propagate from diseased plants. At present,
Table 2. Length of xylem discoloration $(\mathrm{cm})$ in clones of Eucalyptus grandis $\times$ E. urophylla in response to inoculation with two isolates of Ceratocystis fimbriata

\begin{tabular}{llrc}
\hline Clone & $\begin{array}{r}\text { Isolate } \\
\text { C1422 }\end{array}$ & $\begin{array}{r}\text { Isolate } \\
\text { C1345 }\end{array}$ & Control \\
\hline C1 & $48.7 \mathrm{a}^{\mathrm{z}}$ & $31.0 \mathrm{a}^{\mathrm{z}}$ & 1.7 \\
$\mathrm{C} 7$ & $28.2 \mathrm{~b}$ & $11.3 \mathrm{c}$ & 1.7 \\
$\mathrm{C} 9$ & $24.4 \mathrm{bc}$ & $9.0 \mathrm{c}$ & 1.6 \\
$\mathrm{C} 4$ & $22.4 \mathrm{c}$ & $19.0 \mathrm{~b}$ & 1.8 \\
$\mathrm{C} 3$ & $21.6 \mathrm{c}$ & $19.2 \mathrm{~b}$ & 1.8 \\
$\mathrm{C} 6$ & $20.5 \mathrm{c}$ & $11.7 \mathrm{c}$ & 1.8 \\
$\mathrm{C} 10$ & $16.1 \mathrm{~d}$ & $8.9 \mathrm{c}$ & 1.9 \\
$\mathrm{C} 5$ & $15.0 \mathrm{de}$ & $17.5 \mathrm{~b}$ & 1.8 \\
$\mathrm{C} 2$ & $13.7 \mathrm{def}$ & $19.3 \mathrm{~b}$ & 1.7 \\
$\mathrm{C} 11$ & $12.0 \mathrm{ef}$ & $8.8 \mathrm{c}$ & 1.9 \\
$\mathrm{C} 12$ & $10.5 \mathrm{f}$ & $4.3 \mathrm{~d}$ & 1.7 \\
$\mathrm{C} 8$ & $9.7 \mathrm{f}$ & $10.0 \mathrm{c}$ & 1.8 \\
$\mathrm{C} 14$ & $4.3 \mathrm{~g}$ & $4.0 \mathrm{~d}$ & 1.7 \\
$\mathrm{C} 13$ & $4.0 \mathrm{~g}$ & $4.0 \mathrm{~d}$ & 1.7 \\
$\mathrm{C} 15$ & $1.9 \mathrm{~g}$ & $1.9 \mathrm{~d}$ & 1.7 \\
$\mathrm{C} 16$ & $1.8 \mathrm{~g}$ & $1.9 \mathrm{~d}$ & 1.7 \\
$\mathrm{C} 17$ & $1.8 \mathrm{~g}$ & $1.8 \mathrm{~d}$ & 1.6 \\
$\mathrm{C} 18$ & $1.8 \mathrm{~g}$ & $1.7 \mathrm{~d}$ & 1.6 \\
\hline
\end{tabular}

${ }^{\mathrm{z}}$ Means followed by the same letter in a column do not differ significantly (Fisher's protected LSD test, $P<0.05$ ).

however, the disease in eucalyptus appears to be limited to only certain geographic areas of Brazil, where the pathogen may be soilborne (9), and to a limited number of clones. Avoidance of the most susceptible clones and planting highly resistant clones on infested sites appears to be the most effective management option.

\section{ACKNOWLEDGMENTS}

We thank Suzano - Bahia Sul Celulose for logistic assistance and for providing the eucalyptus clones used in this study.

\section{LITERATURE CITED}

1. Baker, C. J., Harrington, T. C., Krauss, U., and Alfenas, A. C. 2003. Genetic variability and host specialization in the Latin American clade of Ceratocystis fimbriata. Phytopathology 93:1274-1284.

2. Barnes, I., Roux, J., Wingfield, B. D., O'Neil, M., and Wingfield, M. J. 2003. Ceratocystis fimbriata infecting Eucalyptus grandis in Uruguay. Australas. Plant Pathol. 32:361-366.

3. CAB International. 2001. Ceratocystis fimbriata. Crop Protection Compendium. CAB International, Wallingford, UK.

4. Castilla, Z. J. 1982. Production de una selección resístanse a llaga macana Ceratocystis fimbriata (Ell. and Halst.) Hunt con relacion a las variedades Tipica y Bordon. Cenicafe 33:53-66.

5. Dominguez, R. P. F., and Velásquez, F. 1972. Selección de plantas de cacao (Theobroma cacao L.) por resistencia al hongo Ceratocystis fimbriata. Rev. Fac. Agron. Univ. Cent. Venez. 6:57-73.

6. Ferreira, F. A., Demuner, A. M., Demuner, N. L., and Pigatto, S. 1999. Murcha-deCeratocystis em eucalipto no Brasil. (Abstr.) Fitopatol. Bras. 24:284.

7. Harrington, T. C. 2000. Host specialization and speciation in the American wilt pathogen Ceratocystis fimbriata. Fitopatol. Bras. 25:262-263.

8. Izquierdo, J. E. 1988. Comportamiento de genotipos de cafetas ante Ceratocystis fimbriata. Cienc. Tec. Agric. Cafe Cacao 1:53-59.

9. Laia, M. L., Alfenas, A. C., and Harrington, T. C. 1999. Isolation, detection in soil, and inocu- 
lation of Ceratocystis fimbriata, causal agent of wilting, die-back and canker in Eucalyptus. Page 77 in: Proc. Bienn. Conf. 12th. Australasian Plant Pathology Society, Canberra, Australia.

10. Malaguti, G. 1956. La necrosis del tronco del cacao en Venezuela. Agron. Trop. 5:207-226.

11. Mora, A. L., and Garcia, C. H. 2000. A Cultura do Eucalipto no Brasil. Sociedade Brasileira de Silvicultura, São Paulo, SP.

12. Roux, J., Coutinho, T. A., Mujuni Byabashaija, D., and Wingfield, M. J. 2001. Diseases of plantation Eucalyptus in Uganda. S. Afr. J. Sci. 97:16-18.

13. Roux, J., Wingfield, M. J., Bouillet, J.-P., Wingfield, B. D., and Alfenas, A. C. 2000 . A serious new wilt disease of Eucalyptus caused by Ceratocystis fimbriata in Central Africa. For. Pathol. 30:175-184.

14. Zuluaga, V., Valencia, A. G., and Gonzalez, J. 1971. Contribucion al estudio de la naturaleza de la resistencia del cafeto a Ceratocystis fimbriata (Ell. \& Halst.) Hunt. Cenicafe 22:43-68. 